\title{
Criminological Outlook of Overcoming Disproportionate Punishment in Environmental Crimes
}

\author{
Mahrus Ali $^{1, *},{\text { Ach } \text { Tahir }^{2}, \text { Faisal }^{3}, \text { Irnawati }^{4}, \text { Pujiyono }^{5} \text { and Barda Nawawi Arief }}^{5}$ \\ ${ }^{1}$ Universitas Islam Indonesia, Indonesia \\ ${ }^{2}$ Universitas Islam Negeri Sunan Kalijaga, Indonesia \\ ${ }^{3}$ Universitas Bangka Belitung, Indonesia \\ ${ }^{4}$ Universitas PGRI Adi Buana Surabaya, Indonesia \\ ${ }^{5}$ Universitas Diponegoro, Indonesia
}

\begin{abstract}
Criminal determination in a number of environmental offenses still raises excessive criminal threats. The weight of a criminal for offense committed due to negligence is even more severe than the weight of the criminal for deliberate offense which causes death. Criminal weights can also not be compared in weight to offenses that have the same level of seriousness. In the Law reviewed, the criminal threat in some formal offenses is more severe than in material offenses so that it violates the principle of proportionality. Excessive crimes can be overcome through ranking offenses based on their seriousness which refers to the four models of criminalization based on environmental losses. The serious environmental pollution model places the most serious offense ranking, followed by the concrete harm model, then the concrete endangerment, and finally the abstract endangerment. After the ranking of environmental offenses is compiled, the criminal weight is determined. Spacing of penalties between the offense groups to another also needs to be determined.
\end{abstract}

Keywords: Disproportionate punishment, environmental law, criminal sanctions, mining law, criminology.

\section{INTRODUCTION}

Theoretical discourse on criminal proportionality in Indonesia is mostly caused by the imposition of criminal sanctions by judges (Mukhtar, 2008; Kholiq \& Wibowo, 2016). This theory is rarely related to how lawmakers determine the threat of criminal sanctions commensurate with the characteristics and seriousness of offense. It is no exaggeration to say that the issue of proportionality is a forgotten issue both in the policy formulation of criminal sanctions and in the discourse of Indonesian criminal law. In fact, the determination of criminal proportionality rests with the legislator. As a mechanism to prevent violations of individual rights, proportionality is placed as a limitation on the power of legislators to threaten criminal sanctions against offense (Ristroph, 2005).

Determination of criminal threats in the formulation of criminal sanctions policies that do not reflect the principle of proportionality will only undermine confidence in criminal justice because it is considered unfair (Schneider, 2012). Determination of such crimes will affect the practice of imprisonment by judges. It is probable that the sentence imposed by the judge raises injustice because the determination of the crime by the

*Address correspondence to this author at the Universitas Islam Indonesia, Indonesia; Tel: +62 274 379178; Fax: +62 274 377043;

E-mail: mahrus_ali@uii.ac.id

E-ISSN: 1929-4409/21 legislator is not based on proportionality. Errors or weaknesses in determining criminal threats by legislators are strategic mistakes that affect criminal law enforcement and crime prevention policies, which in turn result in disproportionate criminal threats (Arief, 2010). This study focuses on overcoming the problem of criminal threats that are disproportionate to a number of environmental offenses. The author limits the concept of disproportionate punishment to severe criminal threats against minor environmental offenses or minor criminal threats against serious environmental offenses.

The limitation of studies on environmental offenses in the environmental law is based on several considerations. Prominent characteristics of environmental crime necessitates intertwining between administrative law and criminal law (Faure et al., 1995). The existence of criminal law serves to make administrative sanctions effective so that there is a possibility of criminal law taking over other fields of law. If so, then the form, duration/weight, and rules for the implementation of criminal penalties must also be oriented to efforts to make administrative sanctions effective (Herlin-Karnell, 2010). Most offenses in the law are administrative violations that cause damage or environmental pollution, but the threat of criminal is relatively severe. Article 105 of the Environmental Protection and Management Law threatens imprisonment for a minimum of 4 years and a

(c) 2021 Lifescience Global 
maximum of 12 years and a fine of at least IDR 4 billion and a maximum of IDR 12 billion for 'everyone who puts waste into the territory of the Republic of Indonesia', while Article 158 The Mining Law threatens a maximum of 10 years imprisonment and a maximum of IDR 10 billion in fines for 'anyone who conducts mining operations without a mining permit.

The first part of this paper describes a theoretical review of disproportionate criminal threats and the author's critical analysis of the concept. Although the definitions of criminal threats presented by experts vary, in general they can be classified into two broad groups, namely criminal threats that are disproportionate in relation to formulation policy by lawmakers and application policies by judges. The second part of this paper analyzes the determination of criminal threats that violate the principle of proportionality in a number of environmental offenses. Researchers argue that the legislators do not yet have guidelines in setting the threat of criminal sanctions so that they often lead to disproportionate punishment. The last part of this article explores strategies to overcome disproportionate punishment in a number of environmental offenses. The author argues that disproportionate punishment can be overcome through ranking offenses based on their seriousness. Environmental offenses need to be grouped according to their seriousness. Environmental offenses that have the same/similar/comparable character need to be placed in the same offense group, and so on. To facilitate this classification, a model of criminalization based on environmental losses that includes abstract endangerment, concrete endangerment, concrete harm, and serious environmental pollution needs to be introduced because its existence reflects the ranking of offense seriousness. After that, the criminal weights will be arranged together with the determination of spacing of penalties in light, moderate, severe and serious environmental offenses.

\section{OVERVIEW OF DISPROPORTIONATE PUNISH- MENT}

Criminal law experts have expressed their opinions on the concept of disproportionate punishment. Schlegel et al. (2000) stated that disproportionate punishment is closely related to the frequent criminal sanctions applied to an act immediately declared as a prohibited act. Disproportionate punishment, thus, represents the imposition of criminal sanctions more often than other available social control responses that are more appropriate and the imposition of criminal sanctions that are not in accordance with their objectives (Schlegel et al., 2000). According to the author, the concept of overpenalization is still abstract because it is unable to distinguish between the imposition of criminal sanctions by judges against defendants found guilty of committing criminal acts with the threatening system of criminal sanctions at the formulation stage by the legislators.

Erik Luna (2004) stated that the concept of disproportionate punishment is related to unclear criminal sanctions in certain cases. More specifically, Luna (2004) interprets disproportionate punishment as 'the abuse of the highest power of the criminal justice system, namely the implementation of crime or the imposition of criminal sanctions without justification', and the form is the threat of disproportionate criminal sanctions. Meanwhile, Sara Sun Beale (2004) conceptualized overpenalization in relation to excessive law enforcement or overenforcement by law enforcement officials in the form of criminal disparities against several perpetrators who commit the same crime.

Darryl K. Brown (2008) defines disproportionate punishment in relation to criminalization policies. Criminalization policies that are carried out inadvertently and not based on rational arguments have the potential to cause disproportionate punishment in the form of severe and excessive crimes that are threatened with minor violations. Roger A. Fairfax Jr. (2011) argues that although the concept of overpenalization proposed by experts differs from one another, but at least the form of excessive criminal threats is associated with the seriousness of offense. The concept of overpenalization by Fairfax Jr. (2011) is substantively the same as the concept put forward by Stephen F. Smith (2012). According to Smith (2012), overpenalization is defined as "undermining the effort to provide just and proportional punishments for offenses". There are two forms of disproportionate punishment according to Smith, namely setting specific minimum criminal threats that have nothing to do with violations or losses incurred, and the severity of criminal threats that do not match the violations or losses incurred.

Paul J. Larkin Jr. (2013) formulating disproportionate punishment as an imposition of criminal threats without justification, while Gregory Jones (2013) states that disproportionate punishment is characterized by the formulation of a special minimum criminal threat that has nothing to do with 
disgrace or loss that underlies a criminal offense. Michael Pierce (2015) defines disproportionate punishment as a very serious crime without adequate reasons, and a heavy sentence for minor violations. Disproportionate punishment stated by experts varies, including; a) too many crimes are threatened and handed down; b) the threat of disproportionate criminal sanctions; c) criminal disparities against several actors who have committed the same crime; d) severe (excessive) crimes that are threatened with minor violations; e) the severity of the criminal threat that is not in accordance with the violation or loss caused; and $f)$ the formulation of special minimum criminal threats that have nothing to do with disgrace or loss that underlies a criminal offense. In this study, the concept of disproportionate punishment is limited to criminal threats disproportionate to the seriousness of offense in the form of two things, namely severe criminal threats against minor offenses, or minor criminal threats against serious or serious offenses.

\section{PORTRAIT OF DISPROPORTIONATE PUNISHMENT}

The Environmental Protection and Management Law still contains a disproportionate criminal threat. Article 99 paragraph (1) threatens imprisonment for a minimum of 1 year and a maximum of 3 years and a fine of at least IDR 1 billion and a maximum of IDR 3 billion for 'everyone who for their negligence has committed an act which results in exceeding ambient air quality standards, water quality standards, seawater quality standards, or environmental damage standard criteria ', while a criminal threat to' every official who intentionally does not supervise the compliance of business and/or activities responsible for laws and regulations and environmental permits resulting in pollution and/or environmental damage which results in loss of human lives' only a maximum of 1 year imprisonment or a maximum fine of IDR 500 million. This provision clearly violates the principle of criminal proportionality. Committed offense which is intentionally conducted and cause damage/pollution to the environment and at the same time death in humans is only threatened with a lower criminal offense that is committed due to negligence. The criminal threat in Article 112 should be more severe than the criminal threat in Article 99 paragraph (1) because it contains a more serious offense character (Berry, 2011). Law on Protection and Management of the Environment also threatens more serious penalties against formal offenses than material offenses as shown in Table 1.

Article 105 constitutes formal offense, but the criminal threat is even more severe than material offense in Article 98 paragraph (1). Prohibited acts in Article 105 are 'enter non- hazardous and toxic materials into the territory of the Republic of Indonesia'. Prohibited acts in Article 106 are 'entering hazardous and toxic materials '. This action has the potential to damage and/or pollute the environment, but this potential is only available if the hazardous and toxic materials is disposed of into environmental media. The element 'thrown into the environment media' does not constitute an offense in Article 106 so it is disproportionate if the criminal threat is more severe than the criminal threat in Article 98 paragraph (2). Based on the principle of proportionality, serious offenses must be threatened with criminal offenses based on their seriousness (Eldar, 2018), and therefore, it is disproportionate if a serious offense

Table 1: Comparison of Criminal Weights between Material Delicts and Formal Delicts in Law on Protection and Management of the Environment

\begin{tabular}{|c|c|c|c|}
\hline Material Delict & Criminal Weights & Formal Delict & Criminal Weights \\
\hline $\begin{array}{l}\text { Deliberately carrying out acts } \\
\text { that result in exceeding ambient } \\
\text { air quality standards, water } \\
\text { quality standards, seawater } \\
\text { quality standards, or } \\
\text { environmental damage standard } \\
\text { criteria (Article } 98 \text { paragraph 1) }\end{array}$ & $\begin{array}{l}\text { Imprisonment for a minimum of } 3 \\
\text { years and a maximum of } 10 \\
\text { years and a minimum fine of IDR } \\
3 \mathrm{M} \text { and a maximum of IDR } 10 \\
\text { billion }\end{array}$ & $\begin{array}{l}\text { Inserting waste into the territory } \\
\text { of the Unitary Republic of } \\
\text { Indonesia (Article 105) }\end{array}$ & $\begin{array}{c}\text { Imprisonment for a minimum of } 4 \\
\text { years and a maximum of } 12 \\
\text { years and a minimum fine of IDR } \\
4 \text { billion and a maximum of IDR } \\
12\end{array}$ \\
\hline $\begin{array}{l}\text { Deliberately carrying out acts } \\
\text { that cause exceeding ambient } \\
\text { air quality standards, water } \\
\text { quality standards, seawater } \\
\text { quality standards, or } \\
\text { environmental damage criteria } \\
\text { that result in people's injuries } \\
\text { and/or human health hazards } \\
\text { (Article } 98 \text { paragraph } 2 \text { ) }\end{array}$ & $\begin{array}{l}\text { Imprisonment for a minimum of } 4 \\
\text { years and a maximum of } 12 \\
\text { years and a maximum fine of } 4 \\
\text { billion and a maximum of IDR } 14 \\
\text { billion }\end{array}$ & $\begin{array}{l}\text { Inserting B3 waste into } \\
\text { Indonesian territory (Article 106) }\end{array}$ & $\begin{array}{c}\text { Imprisonment for a minimum of } 5 \\
\text { years and a maximum of } 15 \\
\text { years and a minimum fine of IDR } \\
5 \text { billion and a maximum of IDR } \\
15 \text { billion }\end{array}$ \\
\hline
\end{tabular}


Table 2: Comparison of Criminal Weights in Former Delict in Law on Protection and Management of the Environment

\begin{tabular}{|c|c|c|}
\hline Delict Formulation & Criminal Weights & Delict Formulation \\
\hline \hline $\begin{array}{c}\text { Conduct dumping of waste and/or } \\
\text { material into the environment } \\
\text { media without permission (Article }\end{array}$ & $\begin{array}{c}\text { The maximum imprisonment of } 3 \\
\text { years and a maximum fine of } \\
\text { IDR } 3 \text { billion }\end{array}$ & $\begin{array}{c}\text { Inserting waste into Indonesian } \\
\text { territory (Article 105) }\end{array}$ \\
$\begin{array}{c}\text { of } 4 \text { years and a maximum of } \\
\text { IDears and a minimum fine } \\
\text { of IDR 4 billion and a } \\
\text { maximum of IDR 12 }\end{array}$ \\
\hline
\end{tabular}

formulated materially is threatened with a lighter criminal offense than a serious offense formulated formally (Manan, 2015). The law threatens different criminal weights against offenses that are formally formulated as in Table 2.

The substance of the offense in Article 105 is more serious than the offense in Article 104 because it has released administrative dependence on criminal law (administrative independent crime), but this offense has been proven if the waste is put into Indonesian territory and is not required to be entered into environmental media. Delict in Article 104 is only proven if the waste or material is disposed of into environmental media without permission. This means that the offense in this article has the character of administrative dependent crime so it is proportional if the criminal threat is lighter than the criminal threat in Article 105. The disproportionate thing is that the criminal threat in Article 105 is far more severe than the criminal threat in Article 104; imprisonment for a minimum of 4 years and a maximum of 12 years and a fine of at least IDR 4 billion and a maximum of IDR 12 billion compared to a maximum imprisonment of 3 years and a maximum fine of IDR 3 billion.

The law also contains the same criminal threat against offenses whose seriousness is different. Article 110 reads everyone who prepares EIA without possessing the competency certificate of the EIA drafter, while Article 111 stated that environmental permit issuing officials who issue environmental licenses without being accompanied by EIA or Environmental Management Efforts - Environmental Monitoring Efforts (UKL-UPL). The criminal threat against these two articles is the same, namely a maximum imprisonment of 3 years and a maximum fine of IDR 3 million. The essence of both offenses is both related to administrative violations, but the offense in Article 111 is more serious because it weakens the legitimacy of government authority and encourages others not to obey the law (Green, 1997). According to proportionality principle, the severity of the criminal threat should not be the same. It asserts that the punishment in the legislation should be appropriate given the harm caused by the particular offense, and it should take into consideration the offender's level of culpability (Martini, 2021. Aguilar, 2020). Equalization of the severity of criminal threats against offenses of different seriousness has implications for the emergence of disproportionate punishment. The criminal threat in Articles 110 and 111 is also more severe than the criminal threat in Article 112 which is only a maximum of 1 year imprisonment or a maximum fine of IDR 500 million, although the offense in Article 112 is far more serious because it is related to the loss of human life. The offenses in the Mining Law can be grouped into two things. This grouping of offenses should have implications for the severity of the threat of criminal sanctions. First is the violation of the permit as regulated in Article 158, Article 160 paragraph (1) and paragraph (2), Article 161 and Article 165. The forms of offense in the form of a permit violation and comparison of criminal weight are shown in Table 3.

Table 3 showed that the criminal weighting against offenses relating to permit violations is different or at least cannot be compared. The criminal weights for violations of 'mining business activities without permit and business license (IUP, IPR or IUPK) (Article 158), and 'accommodating, utilizing, processing and refining, transportation, sale of minerals and coal that are not from holders of permit and business license (IUP, IUPK, or other similar licenses) the form of a maximum imprisonment of 10 years and a maximum fine of IDR 10 billion. The weight of imprisonment for violations in the form of 'having an IUP of Exploration but conducting production operations' is actually lower, which is a maximum of 5 years in prison, even though the weight of criminal penalties is the same. The weight of a criminal offense in the form of 'doing exploration without having an IUP or IUPK' is a maximum imprisonment of 1 year or a maximum fine. In fact, the substance of this offense is the same as the offense in the form of 'conducting mining business activities without IUP, IPR or IUPK'.

Criminal weights against regents/mayors, governors or ministers who 'issue IUP, IPR, or IUPK that 
Table 3: Delicts Related to License Violations in the Mining Law and Comparison of Criminal Weights

\begin{tabular}{|c|c|c|}
\hline Article & Delict Formulation & Criminal Weights \\
\hline 158 & $\begin{array}{l}\text { Everyone who conducts mining business without permit } \\
\text { and business license (IUP, IPR or IUPK) }\end{array}$ & $\begin{array}{l}\text { The maximum imprisonment of } 10 \text { years and a maximum fine of } \\
\qquad \text { IDR } 10 \text { billion }\end{array}$ \\
\hline $160(1)$ & $\begin{array}{c}\text { Everyone who explores without having an business } \\
\text { license (IUP or IUPK) }\end{array}$ & $\begin{array}{l}\text { The maximum sentence of confinement is } 1 \text { year or a maximum } \\
\text { fine of IDR } 200 \text { million }\end{array}$ \\
\hline $160(2)$ & $\begin{array}{l}\text { Everyone who has a permit (IUP) of exploration but is } \\
\text { conducting production operations }\end{array}$ & $\begin{array}{l}\text { The maximum imprisonment of } 5 \text { years and a maximum fine of } \\
\text { IDR } 10 \text { billion }\end{array}$ \\
\hline 161 & $\begin{array}{l}\text { Every person or Production Operation (IUP) holder or } \\
\text { Production Operation PUPK that accommodates, utilizes, } \\
\text { processes and refines, transports, sells minerals and coal } \\
\text { that is not from a permit holder (IUP, IUPK) }\end{array}$ & $\begin{array}{c}\begin{array}{c}\text { Prison for a maximum of } 10 \text { years and a maximum fine of IDR } 10 \\
\text { billion }\end{array}\end{array}$ \\
\hline 165 & $\begin{array}{c}\text { Any person who issues an permit or license (IUP, IPR, or } \\
\text { IUPK) that is contrary to this Law and abuses his } \\
\text { authority }\end{array}$ & $\begin{array}{l}\text { The maximum imprisonment of } 2 \text { years and a maximum fine of } \\
\text { IDR } 200 \text { million }\end{array}$ \\
\hline
\end{tabular}

contradict this Law and abuse their authority' are actually threatened with a maximum imprisonment of 2 years and a maximum fine of IDR 200 million. The weight of this criminal is much lower than the criminal weighting against offense in the form of 'conducting mining business without IUP, IPR or IUPK' which is threatened with a maximum imprisonment of 10 years and a maximum fine of IDR 10 billion. The weight of a crime against an official committing an offense is only a maximum of 2 years imprisonment and a maximum fine of IDR 200 million. The penalties for violating other permits should be lower because they are not related to the position or at least the same because they are both violations of the permit (Headley, 2004; Mardiya, 2018).

\section{OVERCOMING DISPROPORTIONATE PUNISHMENT IN ENVIRONMENTAL OFFENSES}

To overcome disproportionate criminal threats, environmental offenses need to be organized based on their seriousness. This principle entails a corollary of rank-ordering according to which less serious offenses should not be punished with greater severity that more serious offenses (Husak, 2020). This study limits the seriousness of offense in the context of the offense categorization, namely the categorization of an offense based on its seriousness, such as the offense category of light, moderate, severe, and serious. There are two reasons why this needs to be done. First, to fulfill the demands of justice as the ultimate goal of the theory of criminal proportionality. Secondly, the offense graduation system based on its seriousness saves the public prosecutor to prove excessively the offense that actually only needs a light or simple proof (Mandiberg \& Faure, 2009). Criminological perspective shows that there is no consensus regarding the concept of offense seriousness. This concept is also time-bound, in the sense that certain crimes which are considered by the public to be the most serious offenses are not necessarily considered the most serious offenses by the public in the future. Cultural differences also produce different perceptions about the seriousness of offense, even in a community that has a common culture also has a different perception about this concept (O'Connell et al., 1996; Djafar, 2014). Determination of the seriousness of offense in the perspective of criminal law generally refers to two ways (Mandiberg, 2009). The first is referring to the loss or disapproval of an action. This first method refers to the objective element as act in an offense formula such as the loss suffered by the victim or the loss generally suffered by the community as a result of a criminal offense (Torti, 2013; Mandiberg, 2009). Based on this first method, criminal acts which cause physical loss/suffering to victims such as murder are considered as the most serious crimes. Conversely, criminal acts related to property such as theft, fraud and embezzlement are considered lighter than murder (Fisher, 2011). The second is referring to the culpability of offender's mistakes or disapproval, such as factors of intention, motives, and circumstances that accompany violators' disapproval (Von Hirsch, 1983). Crimes committed intentionally are more serious than crimes committed due to negligence.

The seriousness of offense in this study refers to the four models of criminalization based on environmental losses, namely abstract endangerment, concrete endangerment, concrete harm, and serious environmental pollution which actually reflects the offense graduation system based on its seriousness 
both in terms of legal interests to be protected or losses or threats of loss be inflicted. The abstract endangerment model criminalizes environmental damage/pollution only aimed at violating administrative obligations (Faure \& Nisser, 1995; Faure, 2017). The abstract endangerment model indirectly protects ecological values because it limits only to criminal acts that do not involve direct contact between contaminated material and the environment (Mandiberg \& Faure, 2009). This model is based on environmental policies that prioritize licensing and control approaches. Administrative officials in this system play a crucial role because they determine the amount of pollution that is allowed to be discharged into the environment media. They also set emission standards through the use of permits (Faure et al., 1995). This model is also a tendency of a combination of the use of public and private law to prevent environmental damage/pollution (Betlem \& Faure, 1998).

The concrete endangerment model refers to the fact that several types of hazards/threats to environmental values through the determination of the existence of a real threat to the environment as a prerequisite for criminal liability. Abstract dangers/threats are not sufficient for criminal liability because they are considered to be very abstract. This model does not require that the actual loss must be proven, but sufficient to prove the existence of a threat of loss and acts done unlawfully (Faure, 2006; Hartiwiningsih, 2008). Criminalization in this model is done to prevent losses to both humans and the environment (Hoskins, 2018). This model actually protects ecological values directly, but its existence still depends on administrative regulations (Cho, 2000). There are two main characteristics inherent in this model. First is that emissions or pollution can cause threats of loss and that needs to be proven. Second is emissions or pollution carried out unlawfully. As long as administrative rules are followed, the act is not considered a criminal offense if it is done legally. The act is categorized as a criminal offense if it is done unlawfully and can cause a threat of danger (Faure, 2017).

The concrete harm or real loss model is the same as the concrete endangerment model, in that both require proof that the offender violates environmental regulations or administrative procedures. This model also has not released criminal law from administrative dependency. The difference is that the environmental loss in concrete harm must be a real environmental loss, and it is not enough to just be a threat of loss
(Mandiberg \& Faure, 2009). The meaning of environmental losses depends on the approach used. The traditional approach considers that environmental losses are limited to losses experienced by humans such as threats or losses to human health and safety. This approach still relies on environmental law to traditional criminal law which limits humans as victims. Environmental losses can also be assessed from an ecological approach. Specifically, environmental losses in the form of ecosystem damage and degradation, species extinctions, weather changes and global warming, environmental pollution, and losses to animals (Laitos, 2013). Environmental damage/pollution in anthropological perspective can cause loss to the cultural values of a society. The term pinned on this phenomenon is cultural pollution which is the impact of poor environmental work and pornography (Nagle, 2009).

The model of serious environmental pollution has completely freed itself from the administrative dependence of criminal law which is characterized by two ways. First is the elimination of permission as a protector. Even if someone already has permission from an administrative official, if his actions cause serious harm to the environment, then the act is still categorized as a criminal offense. Second is the elimination of unlawful nature as an element of environmental crime. Criminal law can still be used if it causes a very serious loss even if the act is not against the law, in the sense of being done in accordance with permit requirements or administrative regulations.

Criminalized acts under this model are still related to emissions, but the consequences are more serious such as prolonged pollution, serious consequences on human health, and/or severe injury to the population (Faure, 2017). This model aims to criminalize environmental damage/pollution very seriously without seeing whether it is caused by administrative violations. Even if an offender has complied with the permit and its requirements as well as other administrative regulations, the act is still categorized as a criminal offense if it has serious consequences on the environment (Mandiberg \& Faure, 2009). In the context of the environmental law studied, the following table illustrates the ranking of the seriousness of environmental offenses and their criminal weight (Table 4).

Table 4 presented that offenses in the abstract endangerment model fall into the minor offenses group because they are purely administrative violations, there 
Table 4: The Ranking of the Seriousness of the Environmental Offense and its Criminal Gradation

\begin{tabular}{|c|c|c|c|}
\hline Offenses & Model of Criminalization & Rank Offense & Penal Severity \\
\hline $\begin{array}{l}\text { Doing business and/or activity } \\
\text { (UKL-UPL) without having an } \\
\text { environmental permit (Article 109) }\end{array}$ & \multirow{5}{*}{ Abstract Endangerment } & \multirow{5}{*}{ Mild offense group } & \multirow{5}{*}{$\begin{array}{l}\text { Criminal fines of at most } \\
\text { IDR } 1 \text { billion }\end{array}$} \\
\hline $\begin{array}{c}\text { Compile EIA without having a } \\
\text { competency certificate for EIA } \\
\text { drafting (Article 110) }\end{array}$ & & & \\
\hline $\begin{array}{l}\text { To issue an environmental permit } \\
\text { without being equipped with UKL- } \\
\text { UPL or to issue a business and/or } \\
\text { activity permit without being } \\
\text { equipped with an environmental } \\
\text { permit (Article 111). }\end{array}$ & & & \\
\hline $\begin{array}{c}\text { Conducting mining operations } \\
\text { without a People's Mining License } \\
\text { (Article 158) }\end{array}$ & & & \\
\hline $\begin{array}{l}\text { Issue Mining Business Permits, } \\
\text { People's Mining Permits, or Special } \\
\text { Mining Business Permits that } \\
\text { contradict this Law and abuse their } \\
\text { authority (Article 165). }\end{array}$ & & & \\
\hline $\begin{array}{l}\text { Release and/or distribute genetic } \\
\text { engineering products to } \\
\text { environmental media that are in } \\
\text { conflict with environmental permits } \\
\text { (Article 101) }\end{array}$ & \multirow{5}{*}{ Concrete endangerment } & \multirow{5}{*}{ Medium Delict Group } & \multirow{5}{*}{$\begin{array}{c}\text { A maximum fine of IDR } 3 \\
\text { billion }\end{array}$} \\
\hline $\begin{array}{c}\text { Violating wastewater quality } \\
\text { standards, emission quality } \\
\text { standards, or disturbance quality } \\
\text { standards (Article 100) }\end{array}$ & & & \\
\hline $\begin{array}{l}\text { Conduct B3 waste management } \\
\text { without permission (Article 102) }\end{array}$ & & & \\
\hline $\begin{array}{c}\text { Generate hazardous waste and } \\
\text { does not carry out management } \\
\text { (Article 103) }\end{array}$ & & & \\
\hline $\begin{array}{l}\text { Conduct dumping of waste and/or } \\
\text { material into the environment media } \\
\text { without permission (Article 104) }\end{array}$ & & & \\
\hline $\begin{array}{l}\text { Conduct mining business without } \\
\text { IUP or IUPK (Article 158) }\end{array}$ & & & \\
\hline $\begin{array}{l}\text { Exploring without having an IUP } \\
\text { from the Regent, Governor or } \\
\text { Minister or IUPK from the Minister } \\
\text { (Article } 160 \text { paragraph (1) }\end{array}$ & & & \\
\hline \multicolumn{4}{|l|}{$\begin{array}{c}\text { Having an IUP of Exploration but } \\
\text { conducting production operations } \\
\text { (Article } 160 \text { paragraph (2). }\end{array}$} \\
\hline $\begin{array}{l}\text { Authorized officials who deliberately } \\
\text { do not supervise the observance of } \\
\text { the person in charge of the business } \\
\text { and/or activity of the laws and } \\
\text { regulations and environmental } \\
\text { permits that cause pollution and/or } \\
\text { environmental damage resulting in } \\
\text { loss of human life. }\end{array}$ & Concrete Harm & Severe offense group & $\begin{array}{l}\text { Fines of at least } 2 \text { billion } \\
\text { and a maximum of IDR } 5 \\
\text { billion and imprisonment of } \\
\text { at least } 2 \text { years and a } \\
\text { maximum of } 8 \text { years }\end{array}$ \\
\hline $\begin{array}{c}\text { Deliberately carrying out acts that } \\
\text { result in exceeding ambient air } \\
\text { quality standards, water quality } \\
\text { standards, seawater quality } \\
\text { standards, or environmental } \\
\text { damage standard criteria (Article } 98 \\
\text { paragraph 1) }\end{array}$ & Serious environmental pollution & $\begin{array}{l}\text { The delict group is very } \\
\text { serious }\end{array}$ & $\begin{array}{l}\text { Fines of at least } 4 \text { billion } \\
\text { and a maximum of IDR } 12 \\
\text { billion and imprisonment of } \\
\text { at least } 4 \text { years and a } \\
\text { maximum of } 12 \text { years }\end{array}$ \\
\hline
\end{tabular}


(Table 4), continued.

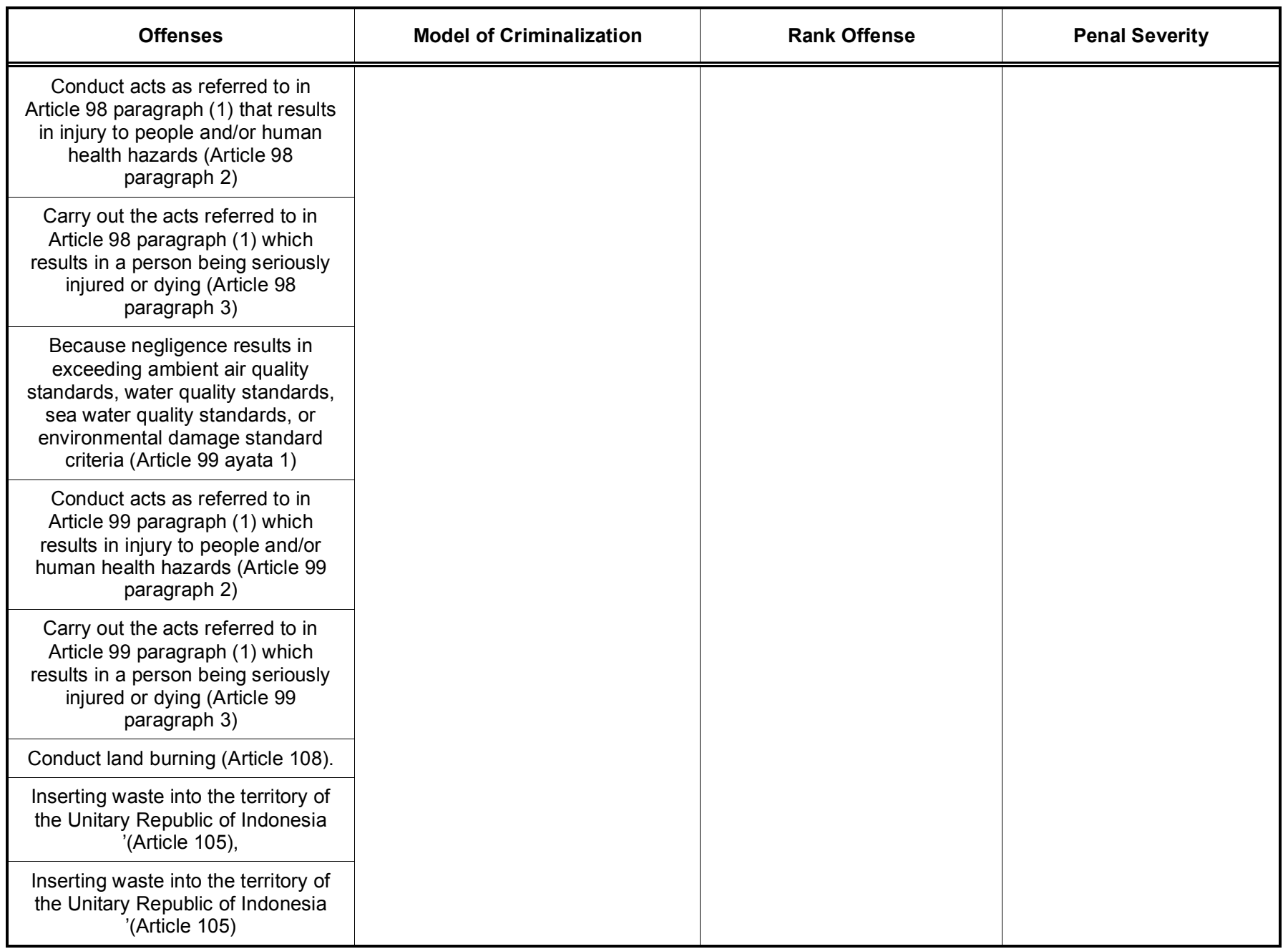

is no direct contact between contaminated material and the environment, and protect ecological values indirectly. These offenses are qualified as a permissible public welfare offense. Violations of these offenses are sufficiently threatened with criminal fines to meet the proportionality requirement that the severity of punishment must weigh the dangerousness of the activity/the blameworthiness of the offense (Phillips, 686). If the fine is not paid by the offender, the property of the convicted person is seized and confiscated by the prosecutor, and auctioned off to pay the fine. If the seized property turns out to be less than the amount of the fine that must be paid, then the convict will undergo a maximum imprisonment of 1 year.

The offenses in the concrete endangerment model are more serious than the offenses in the abstract endangerment model because they directly protect ecological values and the obligation to prove that certain actions are carried out unlawfully, and have the potential to damage or pollute environmental pollution.
All offenses in both models do not need to prove the culpability of an actor which is generally used to 'unsure that one is punished only for choices one has made, not for events one di not will or anticipate'. Although all inherently impose strict liability (Fissel, 862 ), but the threat of crime in the latter offenses is more severe than the offenses of the abstract endangerment model in the form of criminal fines whose weight is heavier than the weight of the penalties in the abstract endangerment offenses because environmental damage or pollution has not yet arisen and still depends entirely on administrative violations.

The offenses in the concrete harm model are more serious than the offenses in the concrete endangerment model because they have caused harm either in the form of damage/environmental pollution or in the form of disruption to health, loss of property or even human life so that the criminal weight is also heavier than the models previous. Against the offenses 
in two previous models, the culpability of the actor like intention is found in the formulation of a delict, and this becomes a basis, according to proportionality principle, to aggrevate the punishment. The wrongness constraint still typically invoke a notion of desert to set limits on punishment (Walen, 2020). Thus, the types of penalties are fines and imprisonment which are formulated cumulatively. Special minimum penalties can be threatened to avoid criminal disparity because the substance is included in severe offense (Harkrisnowo, 2003; Muladi \& Arief, 1984). If a criminal fine is not paid, the convict's property is confiscated and confiscated by the prosecutor, and auctioned off to pay the fine. If the assets seized are apparently less than the amount of the fine that must be paid, then the convicted will be sentenced to a maximum of 2 years imprisonment.

The offenses in the serial environmental pollution model are the most serious offenses because they have freed themselves from the administrative dependence of criminal law, in the sense that certain actions are still categorized as criminal acts if they have very serious consequences on the environment even though the offender maker has complied with the permit or requirements. Other administrative requirements/regulations (Mandiberg \& Faure, 2009), and losses caused more seriously and extreme, such as prolonged pollution, human health, or severe injuries or even to the population (Faure, 2017). From economic perspective, most environmental damages/pollution can be economically quantified, "pricing" the destruction of a universally recognised monument is nearly impossible, and anyway nonsensical (Segate, 2021). The criminal weights that are threatened must also be the heaviest in the form of fines and imprisonment which are cumulatively formulated and special minimum criminal threats. If a criminal fine is not paid, the convict's property is confiscated and confiscated by the prosecutor, and auctioned off to pay the fine. If the assets seized are apparently less than the amount of the fine that must be paid, then the convicted will be sentenced to a maximum of 3 years in prison.

Determination of the severity of a criminal threat based on the seriousness of an offense needs to be followed by spacing of penalties which contains the determination of the distance between the offense group with another offense group both more serious and lighter (Von Hirsch, 1994; Duff \& Garland, 1994). The offenses in the serious environmental pollution model are the most serious offenses compared to the offenses in the concrete harm model, so there needs to be a spacing of penalties between the two. This spacing of penalties also needs to be determined between offenses in the concrete harm model and offenses in the concrete endangerment model and between offenses in the concrete endangerment model and offenses in the abstract endangerment model. The need for a spacing of penalties between serious offense and minor offense, to fulfill justice as the goal of proportionality theory (Green, 2020).

\section{CONCLUSION}

Criminal determination in a number of environmental offenses in the analyzed Law still raises a disproportionate criminal threat. Excessive criminal threats can be overcome by first ranking offenses. The offenses need to be ranked according to their seriousness/categorization. In this research, the models of criminalization based on environmental losses actually reflect the ranking of offenses seriousness. The offenses in the abstract endangerment model are the lightest offenses category so that they are sufficiently threatened with criminal fines that are formulated singly without specific minimum criminal threats.

The offenses in the concrete endangerment model are heavier than the offenses in the abstract endengerment model, therefore, the weight of the criminal penalties is heavier along with the rules for implementing the criminal penalties. The offense in the concrete harm model is more serious than the offense in the concrete endangerment model. The criminal weight must be heavier in the form of imprisonment and fines which are formulated cumulatively, there is a special minimum criminal threat, and there are rules for imprisonment and fines. The offenses in the serious environmental pollution model are the most serious than the other three models so that the weight of the most severe penalties is in the form of imprisonment and fines which are formulated cumulatively, there is a special minimum criminal threat, and there are rules for imprisonment and fines. The research findings are limited to environmental offenses. Hence, it is suggested to further analyse and find the rank-ordering theory for each types of offense since the criteria of proportionality principle is only met when the offenses have been graded according to their seriousness and the culpability of the actor. 


\section{REFERENCES}

Arief, B.N. (2018). Masalah penegakan hukum dan kebijakan hukum pidana dalam penanggulangan kejahatan. Prenada Media.

Aguilar, R. (2021). Unconstitutionally Fining: Fining People Experiencing Homelessness in the Era of Timbs. UIC J. Marshall L. Rev. 53, 598-603

Beale, S. S. (2004). The many faces of overcriminalization: From morals and mattress tags to overfederalization. Am. UL Rev., $54,747$.

Berry III, W. W. (2011). Promulgating Proportionality. Ga. L. Rev., 46, 69.

Betlem, G., \& Faure, M. (1997). Environmental Toxic Torts in Europe: Some Trends in Recovery of Soil Clean-Up Costs and Damages for Personal Injury in the Netherlands, Belgium, England and Germany. Geo. Int'l Envtl. L. Rev., 10, 855.

Brown, D. K. (2008). Prosecutors and Overcriminalization: Thoughts on Political Dynamics and a Doctrinal Response. Ohio St. J. Crim. L., 6, 453.

Cho, B. S. (2000). Emergence of an international environmental criminal law. UCLA J. Envtl. L. \& Pol'y, 19, 11.

Djafar, E. M. (2014). Sinergi Pelaksanaan Penegakan Hukum Lingkungan Indonesia. Jurnal Hukum dan Peradilan, 3(3), 237-242.

https://doi.org/10.25216/JHP.3.3.2014.237-242

Duff, A., \& Garland, D. (1994). A reader on punishment. Oxford University Press

Eldar, S. (2018). Criminal Law, Parental Authority, and the State. Criminal Law and Philosophy, 12(4), 695-705. https://doi.org/10.1007/s11572-017-9452-7

Fairfax Jr, R. A. (2010). From Overcriminalization to Smart on Crime: American Criminal Justice Reform-Legacy and Prospects. JL Econ. \& Pol'y, 7, 597.

Faure, M. (2006). 9. towards a new model of criminalization of environmental pollution: the case of Indonesia. Environmental Law in Development. Lessons from the Indonesian Experience.

Faure, M. (2017). The revolution in environmental criminal law in Europe. Virginia Environmental Law Journal, 35(2), 321-356.

Faure, M. G., Koopmans, I. M., \& Oudijk, J. C. (1995). Imposing criminal liability on government officials under environmental law: a legal and economic analysis. Loy. LA Int'l \& Comp. LJ, $18,529$.

Faure, M., \& Visser, M. (1995). How to Punish Environmental Pollution? Some Reflections on Various Models of Criminalization of Envi https://doi.org/10.1163/157181795X00213

Fisher, G. (2011). Sentencing Severity for'serious' and'significant'Offences: A Statistical Report. Melbourne: Sentencing Advisory Council.

Fissell, Brenner M. (2020). Local Offenses. Fordham L. Rev. 89, 862

Green, S. P. (1997). Why it's a Crime to Tear the Tag off a Mattress: Overcriminalization and the Moral Content of Regulatory Offenses. Emory LJ, 46, 1533.

Green, S. P. (2020). Legal Moralism, Over-inclusive Offenses, and the Problem of Wrongfulness Conflation. Crim. L. \& Phil. 14, 418 https://doi.org/10.1007/s11572-019-09514-8

Harkrisnowo, H. (2003). Rekonstruksi Konsep Pemidanaan: Suatu Gugatan Terhadap Proses Legislasi dan Pemidanaan di Indonesia. Universitas Indonesia, Depok

Hartiwiningsih. (2008). Hukum lingkungan dalam perspektif kebijakan hukum pidana. Sebelas Maret University Press.

Headley, J. (2004). Proportionality Between Crimes, Offenses, and Punishments. . Thomas L. Rev., 17, 247.
Herlin-Karnell, E. (2010). What principles drive (or should drive) european criminal law?. German Law Journal, 11(10), 11151130. https://doi.org/10.1017/S2071832200020137

Hoskins, Z. (2018). Criminalization and the collateral consequences of conviction. Criminal Law and Philosophy, 12(4), 625-639. https://doi.org/10.1007/s11572-017-9449-2

Husak, Douglas. (2020). Criminal Law at the Margins. Crim. L. \& Phil. 14,382 https://doi.org/10.1007/s11572-019-09505-9

Jones, G. (2013). Over-Criminalization and the Need for a Crime Paradigm. Rutgers L. Rev., 66, 931.

Kholiq, M. A., \& Wibowo, A. (2016). Penerapan Teori Tujuan Pemidanaan Dalam Perkara Kekerasan Terhadap Perempuan: Studi Putusan Hakim. Jurnal Hukum IUS QUIA IUSTUM, 23(2), 186-205. https://doi.org/10.20885/iustum.vol23.iss2.art2

Laitos, J. G. (2013). Standing and Environmental Harm: The Double Paradox. Va. Envtl. LJ, 31, 55.

Larkin Jr, P. J. (2013). A Mistake of Law Defense as a Remedy for Overcriminalization. Crim. Just., 28, 10.

Luna, E. (2004). The overcriminalization phenomenon. Am. UL Rev., $54,703$.

Manan, A. (2015). Pencemaran dan Perusakan Lingkungan dalam Perspektif Hukum Islam. Jurnal Hukum dan Peradilan, 4(2), 223-240. https://doi.org/10.25216/JHP.4.2.2015.223-240

Mandiberg, S. F. (2009). Locating the environmental harm in environmental crimes. Utah L. Rev., 1177.

Mandiberg, S. F., \& Faure, M. G. (2009). A graduated punishment approach to environmental crimes: Beyond vindication of administrative authority in the United States and Europe. Colum. J. Envtl. L., 34, 447.

Mardiya, N. Q. A. (2018). Pengaturan pertanggungjawaban korporasi dalam tindak pidana lingkungan hidup/the regulation of corporate liability in environmental criminal act. Jurnal Hukum dan Peradilan, 7(3), 483-502.

https://doi.org/10.25216/JHP.7.3.2018.483-502

Mukhtar, E. (2008). Implementasi teori pemidanaan dalam putusan perkara psikotropika oleh hakim di Pengadilan Negeri Yogyakarta (Doctoral dissertation, Universitas Islam Indonesia).

Muladi, \& Arief, B. N. (1984). Teori-teori dan kebijakan pidana Alumni.

Martini, M. (2021). Pregnancy, Incarcerated: How Incarcerating Pregnant Women in the United States is Incompatible with Theories Justifying Punishment. Hastings Women's L.J, 61, 76-77.

Nagle, J. C. (2009). The idea of pollution. UC Davis L. Rev., 43, 1.

O'connell, M., \& Whelan, A. (1996). Taking wrongs seriously: Public perceptions of crime seriousness. The British Journal of Criminology, 36(2), 299-318. https://doi.org/10.1093/oxfordjournals.bjc.a014087

Pierce, M. (2015). The Court and Overcriminalization. Stan. L. Rev. Online, 68, 50.

Phillips, Kaitlin S. (2020). From Overdose to Crime Scene: The Incompatibility of Drug-Induced Homicide Statutes with Due Process. Duke L.J. 70, 686

Ristroph, A. (2005). Proportionality as a principle of limited government. Duke LJ, 55, 263.

Schlegel, K., Eitle, D., \& Gunkel, S. (2000). Are White-Collar Crimes Overcriminalized-Some Evidence on the Use of Criminal Sanctions against Securities Violators. W. St. UL Rev., 28 117.

Schneider, G. S. (2012). Sentencing Proportionality in the States. Ariz. L. Rev., 54, 241. 
Segate, Riccardo V. (2021). Protecting Cultural Heritage by Recourse to International Environmental Law: Chinese Stances on Faultless State Liability. Hastings Envtl. L.J, 27. 162

Smith, S. F. (2012). Overcoming Overcriminalization. J. Crim. L. \& Criminology, 102, 537.

Torti, J. L. (2013). Accounting for Punishment in Proportionality Review. NYUL Rev., 88, 1908.

Von Hirsch, A. (1983). Commensurability and crime prevention: Evaluating formal sentencing structures and their rationale. J. Crim. L. \& Criminology, 74, 209. https://doi.org/10.2307/1143320
Von Hirsch, A. (1994). Censure and proportionality. A reader on punishment, 128.

Walen, Alec. (2020). Criminal Law and Penal Law: The Wrongness Constraint and a Complementary Forfeiture Model. Crim. L. \& Phil. 14, 434 https://doi.org/10.1007/s11572-019-09515-7

DOI: https://doi.org/10.6000/1929-4409.2021.10.04

(C) 2021 Ali et al.; Licensee Lifescience Global.

This is an open access article licensed under the terms of the Creative Commons Attribution Non-Commercial License (http://creativecommons.org/licenses/by-nc/3.0/) which permits unrestricted, non-commercial use, distribution and reproduction in any medium, provided the work is properly cited. 